\title{
Research on the Manufacture of Moringa Milky Tea
}

\author{
Rui Wang ${ }^{1,2}$, Shiwen $\mathrm{Hu}^{2, *}$, and Qian $\mathrm{Zhou}^{2}$ \\ ${ }^{1}$ Chongqing Collaborative Innovation Center for Functional Food, Chongqing University of Education, Chongqing 400067, China \\ ${ }^{2}$ College of Biological and Chemical Engineering, Chongqing University of Education, Chongqing 400067, China
}

\begin{abstract}
In this research, moringa, black tea, milk powder, white sugar and sucrose ester were used as raw materials, and the optimal processing technology of moringa milky tea was studied by single factor and orthogonal experiments. These results showed that the optimal formula for moringa milky tea was: 7:8 of ratio of tea liquor (black tea liquor: moringa liquor), $11 \%$ of milk powder, $4 \%$ of white sugar and $0.9 \%$ of sucrose ester. Moreover, the milky tea processed with this formula has a strong milk flavor, a delicate and soft taste.
\end{abstract}

\section{Introduction}

Moringa, also known as Drumstick tree, which is a tropical deciduous tree. Moringa has the characteristics of rapid growth and rich nutrition. It is a plant with the function of medicine and food. Moringa contains protein, fat, carbohydrates and dietary fiber in a balanced and appropriate proportion, which can meet people's needs for rich nutrition and lower fat. Each part of moringa has different development value and can be eaten directly. Moringa is also rich in a variety of minerals, vitamins and pharmacologically active ingredients, which can be used in functional food, medical drugs, feed, fertilizers, etc. [1-4]. Tea polyphenols is the general term for polyphenols in tea. It is one of the important ingredients in tea with health care functions. Meanwhile, it has important pharmacological functions such as anti-cancer, anti-aging, anti-radiation, and scavenging human free radicals [5-7]. At present, there are few related beverages produced with moringa as raw materials. Moreover, there is no relevant research on moringa milky tea, and there are no related products on the market. The fusion of milk and tea could produce milk tea with a milky aroma. The milky tea has the dual nutrition of milk and tea. It is one of the home-cooked dishes and is popular all over the world. In this research, single factor and orthogonal experiments were used to study the optimal processing technology of moringa milky tea. It is hoped that the products could retain the nutritional value of black tea and moringa, highlight the flavor of milky tea, and easily accepted by consumers. Moreover, it could produce better social and economic benefits.

\section{Experimental method}

\subsection{Single factor experiment}

\subsubsection{The effects of ratio of tea liquor}

Moringa tea was boiled about 15 minutes on an electric furnace with water at a material-to-liquid ratio of 1:100 [7]. The black tea was heated in a water bath at a material-to-liquid ratio of $1: 75$ for 10 minutes at $90{ }^{\circ} \mathrm{C}$. Then, all the liquid was filtered with suction, and the residue of the tea was removed to prepare tea liquor. To explore the effects of ratio of tea liquor, the total volume of milky tea was set $150 \mathrm{~mL}$. According to the ratio of black tea: moringa tea $(13: 2,11: 4,3: 2,7: 8$ and 1:2), two kinds of teas were taken in a $250 \mathrm{~mL}$ beaker. After that, they were placed in a water bath at $65{ }^{\circ} \mathrm{C}$, and $4.67 \%$ of white sugar was added. Then, $0.3 \%$ of sucrose ester was added and stirred to dissolve. After dissolving, 9.3\% of milk powder was added, then stirred and mixed well.

\subsubsection{The effects of milk powder addition amount}

The mixed tea liquor (the ratio was 7:8) was added with the milk powder at the amount of $5 \%, 8 \%, 11 \%, 14 \%$ and $17 \%$, respectively. Then, $4.67 \%$ of white sugar, $0.33 \%$ of sucrose ester were added and mixed evenly in each milky tea.

\subsubsection{The effects of white sugar addition amount}

The mixed tea liquor (the ratio was 7:8) was added with the white sugar at the amount of $2.5 \%, 3 \%, 3.5 \%, 4 \%$ and $4.5 \%$, respectively. Then, $11 \%$ of milk powder, $0.33 \%$ of sucrose ester were added and mixed evenly in each milky tea.

\footnotetext{
* Corresponding author: wenfeng970211@sohu.com
} 


\subsubsection{The effects of sucrose ester addition amount}

The mixed tea liquor (the ratio was 7:8) was added with the sucrose ester at the amount of $0.3 \%, 0.5 \%, 0.7 \%$, $0.9 \%$ and $1.1 \%$, respectively. After that, $11 \%$ of milk powder, $4.67 \%$ of white sugar were added and mixed evenly in each milky tea.

\subsubsection{Sensory evaluation}

According to the evaluation standard in Table 1, sensory evaluation was performed on the ratio of tea liquor, and the addition amount of milk powder, white sugar, and sucrose ester. Then, the results of the single factor experiment were obtained.

Table 1. Sensory evaluation standard for moringa milky tea.

\begin{tabular}{|c|c|c|}
\hline $\begin{array}{l}\text { Scoring } \\
\text { Item }\end{array}$ & $\begin{array}{l}\text { Sensory Evaluation } \\
\text { Index }\end{array}$ & $\begin{array}{c}\text { Sensory } \\
\text { Evaluation } \\
\text { Scores } \\
\end{array}$ \\
\hline \multirow{3}{*}{$\begin{array}{c}\text { Color } \\
(10 \text { points })\end{array}$} & $\begin{array}{l}\text { milky white with light } \\
\text { brownish yellow, even }\end{array}$ & $\geq 7$ \\
\hline & $\begin{array}{l}\text { milky white to brownish } \\
\text { yellow, even }\end{array}$ & $4-6$ \\
\hline & $\begin{array}{l}\text { milky white to dark brown } \\
\text { yellow, abnormal color }\end{array}$ & $\leq 3$ \\
\hline \multirow{3}{*}{$\begin{array}{c}\text { Shape } \\
\text { (10 points) }\end{array}$} & $\begin{array}{l}\text { good uniform fluidity, } \\
\text { stable }\end{array}$ & $\geq 7$ \\
\hline & $\begin{array}{l}\text { good uniform fluidity, } \\
\text { slight delamination }\end{array}$ & $4-6$ \\
\hline & poor shape & $\leq 3$ \\
\hline \multirow{3}{*}{$\begin{array}{c}\text { Taste } \\
\text { (40 points) }\end{array}$} & fine and smooth taste & $\geq 30$ \\
\hline & soft taste & $12-29$ \\
\hline & average taste & $\leq 11$ \\
\hline \multirow{3}{*}{$\begin{array}{c}\text { Flavor } \\
(40 \text { points })\end{array}$} & $\begin{array}{l}\text { obvious and harmonious } \\
\text { taste, moderate sweetness }\end{array}$ & $\geq 30$ \\
\hline & $\begin{array}{l}\text { average tastes, slightly } \\
\text { sweet }\end{array}$ & $12-29$ \\
\hline & $\begin{array}{l}\text { bad taste, rich sweetness } \\
\text { taste }\end{array}$ & $\leq 11$ \\
\hline
\end{tabular}

\subsection{Orthogonal test}

According to the results of single factor experiment, the sensory evaluation scores of moringa milky tea were optimized via L9 $\left(3^{4}\right)$ orthogonal experiment. Meanwhile, the factors of ratio of tea liquor, the addition amount of milk powder, white sugar, and sucrose ester were included in order to obtain the optimal formula for moringa milky tea.

\section{Results and analysis}

\subsection{The effects of ratio of tea liquor on sensory evaluation}

According to Figure 1, the optimal ratio of tea liquor (black tea: moringa tea) is $7: 8$. In this ratio, the moringa milky tea has the best sensory score. The sensory scores of the ratio of $3: 2$ and $1: 2$, were lower than the ratio of $7: 8$. And the ratio of $13: 2$ and 11:4 were not suitable for the manufacture of moringa milky tea. Therefore, the ratio of tea liquor of 7:8 was the most appropriate ratio.

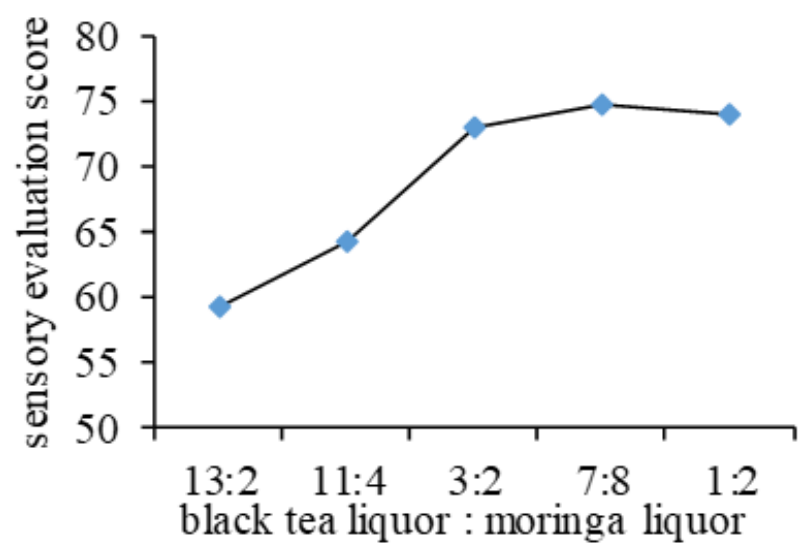

Fig. 1. The effects of ratio of tea liquor on sensory evaluation.

\subsection{The effects of milk powder addition amount on sensory evaluation}

As shown in Figure 2, as the amount of milk powder increased, the sensory scores of milky tea showed a trend of first increasing and then decreasing. The sensory evaluation scores of moringa milky tea was increased to the maximum when the addition amount of milk powder was $11 \%$. However, when the addition amount was continued to increase, the sensory evaluation scores decreased.

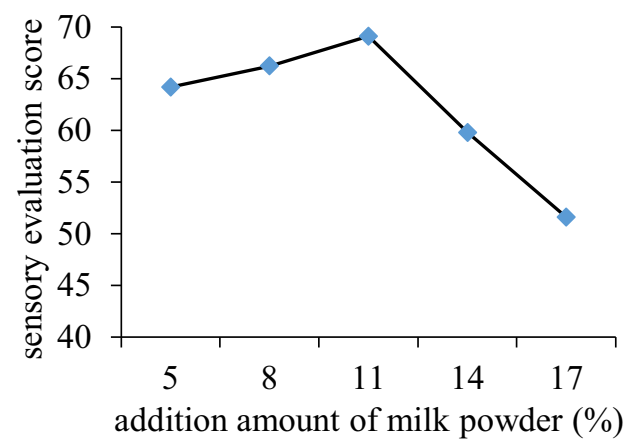

Fig. 2. The effects of addition amount of milk powder on sensory evaluation.

\subsection{The effects of white sugar addition amount on sensory evaluation}

As the amount of white sugar increased, the sensory scores of milky tea showed a trend of first increasing and then decreasing. The sensory evaluation score of 
moringa milky tea was increased to the maximum when the addition amount of white sugar was $4 \%$ (Fig. 3). But the sensory evaluation scores were decreased when the addition amount exceeded $4 \%$.

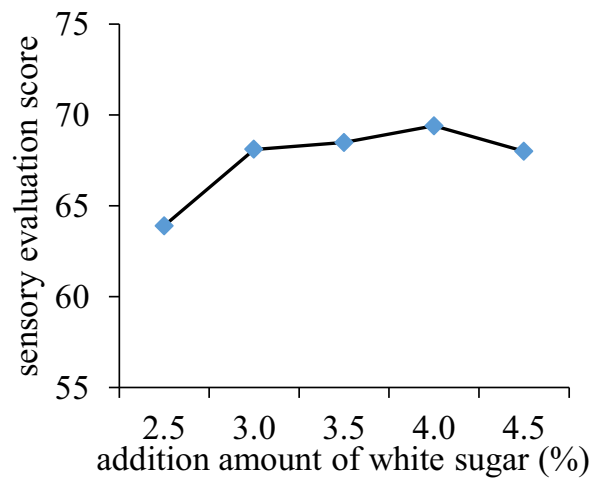

Fig. 3. The effects of addition amount of white sugar on sensory evaluation.

\subsection{The effects of sucrose ester addition amount on sensory evaluation}

According to the experimental data (Fig. 4), as the amount of sucrose ester increased, the sensory scores of milky tea showed a trend of first increasing and then decreasing. When the addition amount of sucrose ester was $0.9 \%$, the sensory evaluation score was reached the highest. However, the sensory evaluation scores gradually declined once the addition amount exceeded $0.9 \%$.

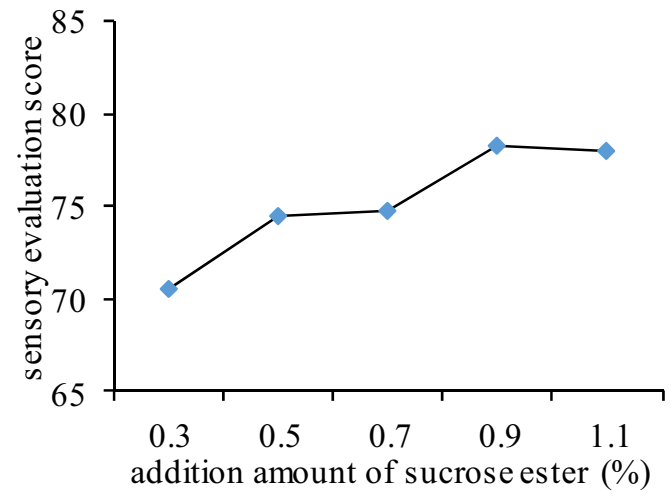

Fig. 4. The effects of addition amount of sucrose ester on sensory evaluation.

\subsection{The results of orthogonal test}

Through the comparison of the sensory scores in Figure1, Figure 2, Figure 3 and Figure 4, the best three levels of each factor were selected (Table 2). According to the best three levels of 4 factors, the orthogonal experiment of L9 $\left(3^{4}\right)$ was designed. Moreover, the sensory evaluations were made from four aspects: color, shape, flavor and taste. The results of orthogonal experiment were shown in Table 3. It could be concluded that the degrees of four factors affecting the sensory evaluations scores were: $\mathrm{C}>\mathrm{B}>\mathrm{A}>\mathrm{D}$. The results showed that factor $\mathrm{C}$ had a maximum impact on sensory evaluation scores, followed by factor $\mathrm{B}$, factor $\mathrm{A}$ and factor $\mathrm{D}$. According to the $\mathrm{K}$ value, the optimal formula was $\mathrm{A}_{2} \mathrm{~B}_{3} \mathrm{C}_{3} \mathrm{D}_{2}$. That means the optimal formula for moringa milky tea was: 7:8 of ratio of tea liquor (black tea liquor: moringa liquor), $11 \%$ of milk powder, $4 \%$ of white sugar, and $0.9 \%$ of sucrose ester.

Table 2. Factors and levels of orthogonal experiments design.

\begin{tabular}{|c|c|c|c|c|}
\hline & $\begin{array}{c}\text { A } \\
\text { ratio of } \\
\text { tea } \\
\text { liquor }\end{array}$ & $\begin{array}{c}\text { B } \\
\text { milk } \\
\text { powder } \\
\mathbf{( \% )}\end{array}$ & $\begin{array}{c}\text { C } \\
\text { white } \\
\text { sugar } \\
\mathbf{( \% )}\end{array}$ & $\begin{array}{c}\text { D } \\
\text { sucrose } \\
\text { ester } \\
\mathbf{( \% )}\end{array}$ \\
\hline 1 & $3: 2$ & 5 & 3 & 0.7 \\
\hline 2 & $7: 8$ & 8 & 3.5 & 0.9 \\
\hline 3 & $1: 2$ & 11 & 4 & 1.1 \\
\hline
\end{tabular}

Table 3. Results and analysis of orthogonal experiments.

\begin{tabular}{|c|c|c|c|c|c|}
\hline entry & $\begin{array}{c}\text { ratio } \\
\text { of tea } \\
\text { liquor }\end{array}$ & $\begin{array}{c}\text { milk } \\
\text { powder } \\
\mathbf{( \% )}\end{array}$ & $\begin{array}{c}\text { white } \\
\text { sugar } \\
\mathbf{( \% )}\end{array}$ & $\begin{array}{c}\text { sucrose } \\
\text { ester } \\
\mathbf{( \% )}\end{array}$ & scores \\
\hline 1 & $3: 2$ & 5 & 3 & 1 & 76.65 \\
\hline 2 & $3: 2$ & 8 & 3.5 & 2 & 80.03 \\
\hline 3 & $3: 2$ & 11 & 4 & 3 & 81.23 \\
\hline 4 & $7: 8$ & 5 & 3.5 & 3 & 75.15 \\
\hline 5 & $7: 8$ & 8 & 4 & 1 & 80.25 \\
\hline 6 & $7: 8$ & 11 & 3 & 2 & 79.05 \\
\hline 7 & $1: 2$ & 5 & 4 & 2 & 79.13 \\
\hline 8 & $1: 2$ & 8 & 3.5 & 3 & 85.65 \\
\hline 9 & $1: 2$ & 11 & 3 & 1 & 84.84 \\
\hline $\mathrm{K}_{1}$ & 196 & 196.9 & 196.2 & 206.1 & \\
\hline $\mathrm{K}_{2}$ & 211.3 & 206.4 & 201.4 & 212.1 & \\
\hline $\mathrm{K}_{3}$ & 208.5 & 212.5 & 218.2 & 197.6 & \\
\hline R & 5.1 & 5.2 & 7.3 & 4.8 & \\
\hline best \\
iondit
\end{tabular}




\subsection{Proof test of the optimal formula}

According to the optimal formula $\mathrm{A}_{2} \mathrm{~B}_{3} \mathrm{C}_{3} \mathrm{D}_{2}$ of the orthogonal experiment, the milky tea was made and evaluated. Three validation experiments were carried out under the optimal formula, and the average sensory evaluations score was 86.03 , indicating the formula was feasible. The results were shown in Table 4.

Table 4. Proof test results of the optimal formula

\begin{tabular}{|c|c|}
\hline Index & sensory evaluation scores \\
\hline Color & 7.17 \\
\hline Shape & 8.32 \\
\hline Taste & 34.23 \\
\hline Flavor & 36.31 \\
\hline
\end{tabular}

\section{Conclusion}

In this research, the optimal processing technology of moringa milky tea was studied by single factor and orthogonal experiments. The results showed that the optimal formula for moringa milky tea was: 7:8 of ratio of tea liquor (black tea liquor: moringa liquor), $11 \%$ of milk powder, $4 \%$ of white sugar, and $0.9 \%$ of sucrose ester, and the average sensory evaluation score was 86.03. The moringa milky tea not only retains the aroma of tea, but also retains the flavor of milk powder. Furthermore, it makes better use of the various characteristics of moringa that are beneficial to the human bodies, and has a good application prospect.

\section{Acknowledgments:}

This research was funded by Teaching Reform Project of Chongqing University of Education (JG201730).

\section{References}

1. H. Sun, S.X. Shi, Y.P. Zhou, J.Z. Yan, Z.H. Ge. Modern Rural Technology, 22 (2016)

2. M.Y. Sun, Y.M. Wang. Journal of Shaoguan University, 12 (2007)

3. Q.Q. Luo. Fujian Science \& Technology of Tropical Crops 43, 39 (2018)

4. X.H. Ma, J.F. Xie, X.Y. Wei, L.J. Liu. Agricultural Research and Application 31, 18 (2018)

5. H.J. Liu, H.B. Li, J. Lai. Journal of Guangzhou City Pohtechnic 5, 56 (2011)

6. F.B. Dang, F. Gao, L. Guo, X.D. Han. Science and Technology of Food Industry 33, 410 (2012) 